\title{
Factors Affecting Monitoring Of the Strategic Plan: A Case of Kenya Seed Company
}

\author{
${ }^{1}$ Dr. Bichanga Walter Okibo, ${ }^{2}$ Edwin Masika \\ ${ }^{I}$ Ph.D. (Senior Lecturer) Jomo Kenyatta University of Agriculture and Technology (Main Campus - Juja), \\ Kenya \\ ${ }_{2}^{2}$ (scholar)Jomo Kenyatta University of Agriculture and Technology, Kitale CBD campus, Kenya
}

\begin{abstract}
Organizations have recently seen the need of planning strategically in order to take stock of the benefits that accrue from having well crafted strategic plans. Kenya Seed Company is an expanding company. The purpose of this study was to establish the factors affecting monitoring of strategic plan at Kenya Seed Company plan. The Strategic Plan of reference was the one that covers the period 2013/2014 to2017/2018.The study was based on the following specific objectives: To find out the role of management on monitoring of strategic plans, to find out the role of resource allocation on monitoring of strategic plans, to find out the role of organization structure on monitoring of strategic plans and to find out the role of communication in monitoring of strategic plans. The study undertook a case study design and targeted a population of 110 employees of Kenya Seed Company among them 54 employees were sampled out to participate in the study. The study adopted used questionnaires as the research instrument. Validity was ensured by asking for advice from the supervisors and other lecturers in the department while reliability was ensured by use of Cronbach's Coefficient Alpha. In data processing and analysis SPPSS was used in computation. Pearson's coefficient of correlation and factorial analysis were also used. Data was presented in tables. The study concluded that leadership is very important for the monitoring of a strategic plan and its implementation in an organization since it's an interpersonal dynamics about the process of influencing others and bringing diverse people together to do purposeful things. The organizational structure is also important in supporting the monitoring of the strategic plan. Communication especially the top-down also plays a key role in ensuring the monitoring of the strategic plan of an organization and finally that an organization's human resource also contributes immensely towards monitoring and implementation of the strategic plan. The study recommended that, management at the company should not only focus on providing leadership alone but also provide adequate resources needed for monitoring of the strategic plan and that the company's organization structure should also be designed to permit interactions. .
\end{abstract}

Key words: Monitoring, Evaluation, Strategic planning, Mission, SWOT Analysis

\section{Background}

Simons (2002) is observes that it is a critical element of the planning process which enables stakeholders to get feedback about performance and monitors strategy implementation. Ittner and Lacker (1998) further demonstrate that monitoring of strategic plans in organizations has attracted a lot of attention in recent years because of the role it plays in strategy development and evaluation of the organizational objectives . This has made them to come up with monitoring strategies in order to realize the success of their strategic plan.

The need for a strategic plan has become necessary at the KSC because of the numerous challenges that it has to grapple with. The challenges are included in the revised strategic plan that covers the period 2013/2014to 2017/2018. To counter this, the company endeavors to introduce superior products in the market besides engaging in continuous quality improvement.

The company plays a crucial role in food production in the country by supplying seeds. This means that there should be enough seeds in store to satisfy growing demand for its products locally and regionally.KSC seeks to buy more land for seed production, increase yield per acre and source for more irrigated land. Another challenge the company has to face is continued government interference in determining the price of maize in the market. This has resulted in lower prices for its products which has in turn affected the company's balance sheet. These challenges made the company come to the realization that in order to perform well it needs to formulate a strategic plan in line with its vision of being the preferred supplier of top quality seed in Africa. A SWOT analysis enabled the company to identify its strengths, weaknesses, threats and opportunities. This analysis was seen as key to the company's efficiency and sustainability. The KSC strengths include having a diversified range of products, a good corporate image, a wide distribution network, a sound financial base, a competent staff and experienced seed growers. The company is also strategically located in Trans -Nzoia District which is the bread basket of the country. 


\section{Statement of the problem}

The strategic plan of 2008/2009 to 2013/2014 was not able to deliver on its objectives because of primarily the non-involvement of other stakeholders in its drafting hence a lack of commitment in implementing the plan.The issue of monitoring of the strategic plan has not been done as expected because of the management style. It was a centralized management style rather than a decentralized one. This created problems in the ownership of the strategic plan by the stakeholders. The organization structure in the strategic plan of 2008/2009 to 2013/2014 was rigid and did not focus on the core competencies of the company. It was also non-optimal. There was inadequate resource allocation and poor communication methods. The management did not involve all the stakeholders which created a problem in the implementation of the previous strategic plan. It adopted a top-down approach instead of a bottom-up. Management needs to understand that apart from just focusing on the formulation and implementation of the strategic plan attention also needs to be placed on monitoring of the plan. Dimma (1985) observes that greater performance is realized when equal emphasis is placed on each component of the strategic planning process.

\section{General objective}

The main objective of the research is to determine the factors affecting monitoring of the strategic plan at Kenya Seed Company

\section{Specific objectives}

i. To find out the role of management in monitoring of the strategic plan.

ii. To find out the role of communication approaches in monitoring of the strategic plan.

iii. To find out the role of the organizational structure in monitoring of strategic plan.

iv. To find out role of resource allocation in monitoring of strategic plan.

\section{Scope of the study}

This research focused on the Strategic Planning process at KSC located in Kit ale. The study targeted a population of 110 employees of Kenya Seed Company among them 54 were sampled out to participate in the study.

\section{Limitations of the study}

Strategic planning is a relatively new concept in organizations. As such, this affected the responses from the sample population. This was compounded by the fact there is little knowledge on strategic planning by most members of the organization.

\section{Literature review}

The literature review in this study reviewed past literature on the factors affecting monitoring of the strategic plan.

\section{Research Gaps}

There has been no sufficient literature on monitoring and evaluation of strategic plans as compared to monitoring of projects. Most of the research in strategic planning at KSC has dwelt on other areas of the process such formulation and implementation. Empirical research in strategic planning has dwelt mainly on the relationship between strategic planning and organizational performance and the role of strategic planning in aiding decision making in the firms (Grant, 2003). This study therefore aims at bridging this gap by shading light on factors affecting monitoring of the strategic plan of a company

\section{Research Methodology}

The study adopted the case study research design because it develops analytic and problem solving skills allows for exploration of solutions for complex issues and allows the researcher to apply new knowledge and skills. The research targeted the employees of Kenya Seed Company. The research targeted 6 senior management level employees, 15 heads of department and 89 operational level employees. The target population was therefore 110 employees. The study employed stratified sampling technique and purposive sampling technique in selecting the respondents. Stratified sampling technique was used to select 33 employees from the departments of Kenya Seed Company. Purposive sampling technique was used to select the management level employees and 15 head of departments. 
Table 1: Sample size

\begin{tabular}{llll}
\hline Respondents & Target population & Procedure & Sample size \\
\hline Senior management level & 6 & - & 6 \\
Head of departments & 15 & - & 15 \\
Employees & 89 & $110 * 0.3$ & 33 \\
Total & $\mathbf{1 1 0}$ & & $\mathbf{5 4}$ \\
\hline
\end{tabular}

\section{Instruments of Data Collection}

The questionnaires were used to seek for responses from respondents based on the research objectives. Questionnaires were administered to all other employees in various departments. Most of the items adopted a Lickert scale (such as 1 -strongly disagree, 2-disagree, 3-undecided, 4-agree, 5-strongly agree).

\section{Data Processing and Analysis}

The study used descriptive and inferential analysis techniques to analyze data. The descriptive statistic used was the mean which indicates the average performance of a group or a measure of some variable. The inferential statistics included the correlation relationships of the different variables. Tables were used in data presentation. This was done with the aid of a computer programme - Statistical Package for Social Sciences (SPSS) version 17.0 for Windows.

\section{Research findings and discussions}

Effect of management styles on monitoring of the strategic plan

Key: F: Frequency, \%: Percentage, SA: Strongly Agree, A: Agree, UD: Undecided, D: Disagree, SD: Strongly Disagree, T: Total, M: Mean, SD: Standard Deviation

\begin{tabular}{|c|c|c|c|c|c|c|c|c|}
\hline & & SA & $\mathbf{A}$ & UD & $\mathbf{D}$ & SD & $\mathbf{T}$ & M \\
\hline Senior management has been in the & $\mathrm{F}$ & 1 & 4 & 6 & 37 & 5 & 53 & 3.8 \\
\hline $\begin{array}{l}\text { forefront in providing leadership to enable } \\
\text { monitoring of strategic plan }\end{array}$ & $\%$ & 1.9 & 7.5 & 11.3 & 69.8 & 9.4 & 100 & $(76 \%)$ \\
\hline $\begin{array}{l}\text { managers, supervisors)have the skills to } \\
\text { enable successful monitoring }\end{array}$ & $\%$ & 5.7 & 1.9 & 11.3 & 75.5 & 5.7 & 100 & $(74 \%)$ \\
\hline Management provides the resources needed & $\mathrm{F}$ & 1 & 7 & 17 & 26 & 2 & 53 & 3.4 \\
\hline $\begin{array}{l}\text { management support monitoring of the } \\
\text { implementation of the plan }\end{array}$ & $\%$ & 1.9 & 13.2 & 24.5 & 58.5 & 1.9 & 100 & $(70 \%)$ \\
\hline
\end{tabular}

According to the study conducted on the Kenya seed company, $76 \%$ of the respondents were of the opinion that senior management has been in the forefront in the providing leadership to enable monitoring of strategic plan, $74 \%$ of the respondents were of the opinion that management staff (directors ,seniors ,managers, supervisor) have the skills to enable successful monitoring $70 \%$ were of the opinion that systems and procedures established by management support monitoring of the implementation of the plan while $68 \%$ were for the opinion that management provides the resources needed for monitoring of the plan.

This could be interpreted to mean that Kenya Seed Company management's main role is to provide the leadership towards monitoring and implementation of the strategic plan

These findings are in agreement with Mintzberg (1973) view that leadership is at the heart of the manager-subordinate relationship and managerial power where subordinates are involved even where perhaps the relationship is not directly interpersonal.

The findings also concur with managerial functions of planning, organizing, commanding, coordinating, and controlling to realize the company's strategic plan. Fayol (1925) held that effective management entails a good plan of action which should be flexible, continuous, relevant and accurate, focusing on the nature, priorities and condition of the company. The concept of goal setting is used to increase the performance of the company through management by objectives (Drucker, 1954). 


\section{Effect of organization structure on monitoring of the strategic plan}

Key: F: Frequency, \%: Percentage, SA: Strongly Agree, A: Agree, UD: Undecided, D: Disagree, SD: Strongly Disagree, T: Total, M: Mean, SD: Standard Deviation

\begin{tabular}{|c|c|c|c|c|c|c|c|c|}
\hline & & $\mathbf{S A}$ & $\mathbf{A}$ & UD & D & SD & $\mathbf{T}$ & $\mathbf{M}$ \\
\hline \multirow{2}{*}{$\begin{array}{l}\text { The organization structure } \\
\text { monitoring of the strategic plan }\end{array}$} & $\mathrm{F}$ & 1 & 3 & 5 & 38 & 6 & 53 & \multirow{2}{*}{$\begin{array}{l}3.8 \\
(76 \%)\end{array}$} \\
\hline & $\%$ & 1.9 & 5.7 & 9.4 & 71.7 & 11.3 & 100 & \\
\hline \multirow{2}{*}{$\begin{array}{l}\text { There has been a change in the since the } \\
\text { launch of the current strategic plan }\end{array}$} & $\mathrm{F}$ & 3 & 3 & 8 & 33 & 6 & 53 & \multirow{2}{*}{$\begin{array}{l}3.7 \\
(74 \%)\end{array}$} \\
\hline & $\%$ & 5.7 & 5.7 & 15.1 & 62.3 & 11.3 & 100 & \\
\hline \multirow{2}{*}{$\begin{array}{l}\text { The structure permits both vertical and } \\
\text { horizontal interactions and promotes } \\
\text { teamwork }\end{array}$} & $\mathrm{F}$ & 4 & 12 & 16 & 17 & 4 & 53 & \multirow{2}{*}{$\begin{array}{l}3.1 \\
(62 \%)\end{array}$} \\
\hline & $\%$ & 7.5 & 22.6 & 30.2 & 32.1 & 7.5 & 100 & \\
\hline \multirow{2}{*}{$\begin{array}{l}\text { There is effective delegation and control of } \\
\text { management }\end{array}$} & $\mathrm{F}$ & 2 & 10 & 18 & 20 & 3 & 53 & \multirow{2}{*}{$\begin{array}{l}3.2 \\
(64 \%)\end{array}$} \\
\hline & $\%$ & 3.8 & 18.9 & 3.4 & 37.7 & 5.7 & 100 & \\
\hline
\end{tabular}

According to the study conducted, it is evident that $76 \%$ of the respondents agreed with the opinion that the organization structure supports monitoring of the strategic plan while $74 \%$ were of the opinion that there has been a change in the since the launch of the current strategic plan, $64 \%$ were of the opinion that there is effective delegation and control of management while $62 \%$ were of the opinion that the structure permits both vertical and horizontal interactions and promotes teamwork.

This could be interpreted to mean that the organization structure of Kenya Seed Company is effective in supporting the implementation of the strategic plan. This could be so because the company's theme is effectively transformed into corporate priorities and objectives at each level of the organization.

These findings are in agreement with the Systems theory (Albrecht, 1983) which describes the interrelatedness of all parts of an organization and how one change in one area can affect multiple other parts. Systems may not always interact in a lineal manner hence small changes in one part may cause big changes in another part, while large changes in one area may only result in small changes in another. Therefore, from the findings, the Kenya Seed Company's organizational structure acts as a system interacting with its environment whereby the different components of the company are required to operate in an organized and correlated manner. For effective monitoring of the strategic plan, the interaction between the various systems is contingent upon the linking processes, which consist of communication, balance and decision making which the company's organizational structure supports. The company management's organizational structure style is also in agreement with Nico Long (2010) views on structural contingency suggest that companies have a plan in place to guide organizational change when necessary. According to renowned management theorist Mintzberg (1973), an organization's structure emerges from the interplay of the organization's strategy, the environmental forces it experiences, and the organizational structure itself.

Table 4.7 Effect of communication approaches on monitoring of the strategic plan

Key: F: Frequency, \%: Percentage, SA: Strongly Agree, A: Agree, UD: Undecided, D: Disagree, SD: Strongly Disagree, T: Total, M: Mean, SD: Standard Deviation

\begin{tabular}{|c|c|c|c|c|c|c|c|c|}
\hline & & SA & $\mathbf{A}$ & UD & D & SD & SA & $\mathbf{M}$ \\
\hline \multirow{2}{*}{$\begin{array}{l}\text { There is adequate and consistent } \\
\text { communication at each level of the } \\
\text { monitoring process }\end{array}$} & $\bar{F}$ & 1 & 5 & 8 & 23 & 6 & 53 & \multirow[t]{2}{*}{$\begin{array}{l}3.3 \\
66 \%\end{array}$} \\
\hline & $\%$ & 1.9 & 28.3 & 15.1 & 43.4 & 11.3 & 100 & \\
\hline \multirow{2}{*}{$\begin{array}{l}\text { Information technology is used to } \\
\text { facilitate communication }\end{array}$} & F & 1 & 5 & 5 & 33 & 9 & 53 & \multirow{2}{*}{$\begin{array}{l}3.8 \\
76 \%\end{array}$} \\
\hline & $\%$ & 1.9 & 9.4 & 9.4 & 62.3 & 17.0 & 100 & \\
\hline \multirow[t]{2}{*}{ Communication is timely and fast } & $\mathrm{F}$ & 1 & 14 & 12 & 20 & 6 & 53 & \multirow{2}{*}{$\begin{array}{l}3.3 \\
66 \%\end{array}$} \\
\hline & $\%$ & 1.9 & 26.4 & 22.6 & 37.7 & 11.3 & 100 & \\
\hline \multirow[t]{2}{*}{$\begin{array}{l}\text { It gives feedback to management and } \\
\text { employees about the monitoring process }\end{array}$} & $\mathrm{F}$ & 3 & 16 & 8 & 23 & 3 & 53 & \multirow[t]{2}{*}{$\begin{array}{l}3.1 \\
62 \%\end{array}$} \\
\hline & $\%$ & 5.7 & 30.2 & 15.1 & 43.4 & 5.7 & 100 & \\
\hline
\end{tabular}

According to the study $76 \%$ of the respondents were of the opinion that information technology is used to facilitate communication, $66 \%$ were of the opinion that there is adequate and consistent communication at each level of the monitoring process, $66 \%$ were also of the opinion that communication is timely and fast while $62 \%$ were of the opinion that communication gives feedback to management and employees about the monitoring process. 
The findings also concur with the adaptive structuration theory (Giddens, 1984) which holds that groups and organizations using information technology for their work dynamically create perceptions about the role and utility of the technology, and how it can be applied to their activities.

Management's adoption of information systems also concur with MacKechnie's (2006) view on the vital role of information systems. He held that storing data is only a benefit if that data can be used effectively. Progressive companies use data as part of their strategic planning process as well as the tactical execution of that strategy. Information systems thus enable the company to track the monitoring of the strategic plan. The findings also agree to Daft \& Lengel's (1984) media richness theory which is based on contingency theory and information processing theory (Galbraith 1977). Daft and Lengel (1984) proposed that communication media have varying capacities for resolving ambiguity, negotiating varying interpretations, and facilitating understanding. Two main assumptions of this theory are: people want to overcome equivocality; and, uncertainty in organizations and a variety of media commonly used in organizations work better for certain tasks than others. Daft and Lengel (1984) presented a media richness hierarchy to illustrate the capacity of media types to process ambiguous communication in organizations. From a strategic management perspective, management at the company and just as the media richness theory suggests, makes rational choices matching a particular communication medium to a specific task or objective and to the degree of richness required by that task. The task, in this case, is monitoring and eventual implementation of the strategic plan.

TABLE 4.8 Effect of resource allocation on monitoring of the strategic plan

Key: F: Frequency, \%: Percentage, SA: Strongly Agree, A: Agree, UD: Undecided, D: A Disagree, SD: Strongly Disagree, T: Total, M: Mean, SD: Standard Deviation

\begin{tabular}{|c|c|c|c|c|c|c|c|c|}
\hline & & $\mathbf{S A}$ & $\mathbf{A}$ & UD & D & SD & $\mathbf{T}$ & $\mathbf{M}$ \\
\hline \multirow[t]{2}{*}{ There is a separate monitoring budget } & $\bar{F}$ & 5 & 9 & 17 & 19 & 2 & 53 & \multirow{2}{*}{$\begin{array}{l}3.1 \\
(62 \%)\end{array}$} \\
\hline & $\%$ & 9.4 & 17 & 32.1 & 3.8 & 98.1 & 100 & \\
\hline \multirow{2}{*}{$\begin{array}{l}\text { Employee training is geared towards monitoring of } \\
\text { the implementation of the strategic plan }\end{array}$} & $\mathrm{F}$ & 3 & 15 & 11 & 20 & 4 & 53 & \multirow{2}{*}{$\begin{array}{l}3.1 \\
(62 \%)\end{array}$} \\
\hline & $\%$ & 5.7 & 28.3 & 20.8 & 37.7 & 7.5 & 100 & \\
\hline \multirow{2}{*}{$\begin{array}{l}\text { Recruitment policy of the company supports } \\
\text { monitoring }\end{array}$} & $\mathrm{F}$ & 3 & 8 & 11 & 20 & 1 & 53 & \multirow{2}{*}{$\begin{array}{l}3.0 \\
(60 \%)\end{array}$} \\
\hline & $\%$ & 5.7 & 34 & 20.8 & 37.7 & 1.9 & 100 & \\
\hline \multirow{2}{*}{$\begin{array}{l}\text { The company has a database of skills and } \\
\text { experiences and is regularly updated to support } \\
\text { monitoring of the strategic plan }\end{array}$} & $\mathrm{F}$ & 4 & 7 & 12 & 26 & 4 & 53 & \multirow{2}{*}{$\begin{array}{l}3.4 \\
(68 \%)\end{array}$} \\
\hline & $\%$ & 7.5 & 13.2 & 22.6 & 49.1 & 7.5 & 100 & \\
\hline
\end{tabular}

According to the study conducted $68 \%$ of the employees were of the opinion that the company has a database of skills and experience and is regularly updated to support monitoring of the strategic plan, $62 \%$ were for the opinion that there is a separate monitoring budget, and also $62 \%$ were for opinion that employees training is geared towards monitoring the implementation while $60 \%$ where for the opinion that recruitment policy of the company supports monitoring.

This could be interpreted to mean that Kenya Seed Company keeps a database of skills and experiences as a backup plan in case of any emergencies, for example, when an employee falls sick or terminates his/her employment contract abruptly and with short notice. This strategy is very important to the company because it has strict delivery schedules and therefore it saves the company on time wasted through the rigorous recruitment and training process. This further shows that the company is very keen on continuity as a factor of production because any organization that experiences an acute interruption in service delivery, especially supplies, can easily affect the vital supplier-reseller/client relationship that is essential for business.

These findings are in agreement with the contingency theory (Fielder, 1960) that primarily deals with conflict, which previous theories considered something to be avoided at all costs. Conflict is unavoidable, but according to contingency theory it is manageable. Organizations evolve to meet their own strategic needs in rational, sequential and linear ways hence adapting to changes in the environment is important to managerial and organizational success. Management at Kenya Seed Company share in the same opinion with Fielder that there cannot be universal guidelines which are suitable for all situations hence different environments require different organizational relationships for optimum effectiveness. The situational leadership theory (Hersey and Blanchard, 1969) is also in line with the contingency plan employed by Kenya Seed Company's management policy on resource allocation. The theory asserts that leadership effectiveness depends on the leader's ability to tailor his or her behavior to the demands of the situation. It contributes to the understanding of leadership effectiveness by underlining the need for leaders to adapt their behavior to different situations. These findings also attest to House (1971) Path-Goal theory which assumes that a leader's key function is to adjust his/her behaviors by providing what is missing in the situational contingencies, such as those in the work setting. Aspects of the situation such as the nature of the task, the work environment, and subordinate attributes (e.g., 
ability) determine the optimal amount of each type of leader behavior (directive, supportive, achievementoriented, and participative) for improving organizational performance. Vroom and Yetton's (1932) normative decision theory asserts that the effectiveness of a decision procedure depends upon a number of aspects of the situation, the importance of the decision quality and acceptance being one of them.

\section{Summary}

\section{Summary, Conclusions and Recommendations}

According to the study conducted at the Kenya seed company, a majority (76\%) of the respondents were of the opinion that senior management has been in the forefront in the providing leadership to enable monitoring of strategic plan. This could be interpreted to mean that Kenya Seed Company management's main role is to provide the leadership towards monitoring and implementation of the strategic plan. This could be because most employees at the company lack the ability to make strategic decisions on their own. The study also established that a majority (76\%) of the respondents agreed with the opinion that the organization structure supports monitoring of the strategic plan. This could be interpreted to mean that the organization structure of Kenya Seed Company is effective in supporting the implementation of the strategic plan. This could be so because the company's theme is effectively transformed into corporate priorities and objectives at each level of the organization. The study also established that a majority $(76 \%)$ of the respondents were of the opinion that information technology is used to facilitate communication. This could be interpreted to mean that Kenya Seed Company has an integrated information system designed to facilitate the monitoring of the strategic plan. The study also established that a majority $(68 \%)$ of the employees were of the opinion that the company has a database of skills and experience and is regularly updated to support monitoring of the strategic plan. This could be interpreted to mean that Kenya Seed Company keeps a database of skills and experiences as a backup plan in case of any emergencies, for example, when an employee falls sick or terminates his/her employment contract abruptly and with short notice. S

\section{Conclusion}

Leadership is very important for the monitoring of a strategic plan and its implementation in an organization since it's an interpersonal dynamics about the process of influencing others and bringing diverse people together to do purposeful things. However, leadership in an organization alone is not enough. The organizational structure is also important in supporting the implementation of the strategic plan.. A properly designed organization structure facilitates the completion of projects hence project managers can better identify the human resources available to them if the scope of each department's responsibility and each team member's capabilities are clear.

\section{Recommendation}

Management at the company should not only focus on providing leadership alone but also provide adequate resources needed for monitoring of the strategic plan. Top management has the responsibility and authority for provision of resources.

The company's organization structure should also be designed to permit both the vertical and horizontal interactions and promote teamwork too. The company's organizational structure could be the traditional type which creates vertical and horizontal boundaries impeding communication. The recruitment policy of the company should also be formulated to support monitoring of the strategic plan. This is because adequate human resource is a key component for the implementation of the strategic plan to be effective.

\section{References}

[1]. Alexander, L.D, (1985): Successfully implementing strategic Decisions, Long range planning, Prentice Hall Allison, M., \&Kaye, J. (2005).Strategic planning for Non-Profit Organizations: A practical workbook ( $2^{\text {nd }}$ ed).San Francisco: John Wileys \&Sons Inc.

Ansoff, I. (1990). (Eds): Implanting Strategic Management. Europe: Prentice Hall.

[3]. Anthony, R.N.and Govindarajan, V. (1985).Management Control Systems. Richard, D.Irwin, Inc, USA

[4]. Aosa, E, (1992): An empirical investigation of aspects of Strategy and formulation implementation within large, private manufacturing companies in Kenya(Unpublished PhD thesis, University of Strathclyde,Scotland)

[5]. Argyris, C and Donald, S. (1974). Theory in Practice. Jossey-Bass Australasian Evaluation Society (1998).Guidelines for the ethical conduct of evaluations.

[6]. Armstrong, J.S. (1982). The value of formal planning for strategic decisions: Review of empirical research. Strategic management journal, 3, pp.197-211.

[7]. Backoff, R. \&Nutt, P. (1988).A Process for Strategic Management with Application for the Non-Profit Organization, in Strategic Planning: Threats and Opportunities for Planners. Chicago: Planner's Press.

[8]. Barney, J.B. (1991). "Firm resources and sustained competitive advantage".Journal ofManagement, Vol. 17, pp. 99-120.

[9]. Beauregard, R. A. (1995). "Edge Critics." Journal of Planning Education.

[10]. Boyd, K.B. (1991). "Strategic planning and financial performance: a meta-analytic review".

[11]. Bryman, A. and Bell, E. (2003). Business Research Methods. Oxford University Press Inc, Bryson, J.M. (1994). Strategic planning and action planning for nonprofit organizations. San Francisco: Jossey-Bass Publishers.

[12]. Buchanan V. and Boddy N. (1992). Dysfunctional effects of formal planning: two theoretical explanations, Academy of Management Review, Vol. 8 pp.588-99 
[13]. Burgelman, R. A. (1994) 'Fading memories - a process theory of strategic business exit', Administrative Science Quarterly, Vol. 39, No.1.

[14]. Covey, S. R. (1994). First things first. New York: Simon and Schuster David, F. (2003).Strategic Management. Concepts and Cases. New Jersey: Prentice Hall.

[15]. Davidson, E.( 2000), Ascertaining causality in theory-based evaluation, in Program Theory. Diem,K.(2002).Using Research Methods to Evaluate Your Extension Program.Journal of Extension,40(6).Pp. 412-115.

[16]. Dimmer, W.A. (1985).'Competitive Strategic Planning'. Business Quarterly, Spring.

[17]. Donnelly, J.H., Gibson, J.L., and Ivancevich, J.M. (1998). Fundamentals of Management. (10th ed.). Chicago: Richard D. Irwin. 85

[18]. Drucker, P. (1974).The Practice of Management. Oxford: Butterworth-Heinemann.

[19]. Drucker, P. (1974). Management: tasks, responsibilities, and practices. New York: Harper \& Row Publishers.

[20]. Fischler, R. (1995). "Planning Theory as Culture and Experience." Journal of

[21]. Frankel, J.R. and Wallen, N.E. (2000).How to design and evaluate research in education, London, UK: McGraw Hill.

[22]. Govindarajan, V. (1988). „A Contingency Approach to Strategy Implementation at the Business-Unit Level Integrating Administrative Mechanisms With Strategy"e. Academy of Management Journal, 31, 828-853.

[23]. Govindarajan, V. (1989). ,Implementing Competitive Strategies at the Business Unit Level: Implications of Matching Managers to Strategies"e. Strategic Management Journal, 10, 251-269.

[24]. Giné, X. and D. Karlan (2006). "Group versus Individual Liability: Evidence from a Field Experiment in the Philippines," Yale University Economic Growth Center working paper 940.

[25]. Grant, R.M. (2003), "Strategic planning in a turbulent environment: evidence from the oil majors". Strategic Management Journal, Vol. 24, pp. 491-517.

[26]. Greenley, G.E. (1986). “Does strategic planning improve company performance?”, Long RangePlanning, pp. 101-9.

[27]. Gyorkos,T.(2003:Monitoring and Evaluation of Large Scale HelminthControl Programmes.Acta Tropic,86,(2),pp.275-285.

[28]. Hardjono, T.W, \& Barker, R.J.M. (2008).Management van Processn: identificeren, besturen, beheersen, envernieuwen, Kluwer, Deventer.

[29]. Hawe, P., Degeling, D. and Hall,J(1992).Evaluating Health Promotion. A health worker's guide. MacLennan and Petty, Sydney.

[30]. Hopkins, W.E. and Hopkins, S.A. (1997). "Strategic planning-financial performance relationship in banks: a causal examination". Strategic Management Journal, Vol. 18 No. 8, pp. 635-52.

[31]. Hussey, J\& Hussey, R. (1997).Business Research: A practical guide for undergraduate and postgraduate students. Palgrave, New York.

[32]. Ittner, C. \&Larcker, D. (1998).Are non-financial measures leading indicators of financial performance? An analysis of customer satisfaction: Journal of Accounting Research, Vol.36, No.3.

[33]. James,R(2002).People and Change: Exploring Capacity Building in NGOS.Oxford.INTRAC Journal of Management Studies, Vol. 28, pp. 353-74.

[34]. Jody, Z and Ray, R.(2004).Ten steps to a result based monitoring and evaluation system: AHandbook for Development practitioners. Washington: World Bank

[35]. Johnson, G.,Scholes, K., and Whittington, R. (2006). (Eds): Exploring Corporate Strategy. London :Prentice Hall.

[36]. Khakee, A and Stromberg, K, (1993). Applying futures studies and the strategic choice approach in urban planning. Journal of the Operational Research Society 44(3), 213-224.

[37]. Kerlinger, F.N. (1973).Foundations of Behavioral Research.Holt, Rinehart \&Winston, New York.

[38]. Kothari,C.(2003):Research methodology: Research Methods and Techniques.Kisha Prakasham,New Delhi.

[39]. Kombo, D.K. \& Tromp, D.L.A. (2006), Proposal and Thesis Writing: An Introduction. Nairobi, Kenya: Pauline's Publications for Africa.

[40]. Kotler, P. (1997), Marketing Management, Analysis, Planning, Implementation and Kremer, M. and E. A. Miguel (2007). "The Illusion of Sustainability," Quarterly Journal

[41]. Mintzberg, H. (1987).The Five P'S of Strategy. California Management Review.Vol.30 No.1 pp.11-24

[42]. Mugenda, Oand Mugenda, A. (2003).Research methods Quantitative and Qualititative.Approaches, Nairobi Acts Press.

[43]. Muthuiya, F.A (2004): Strategy implementation and it challenges in nonprofit organizations in Kenya: The case of AMREF Kenya.(Unpublished MBA Research project, University of Nairobi)

[44]. Mislevy, R.J.(2004).Can there be reliability without 'reliability'? Journal of Educational \& Behavioral Statistics,Vol.29,NO.2

[45]. Naryanan, V.K, and Nath, R. (1993).Organization Theory: Strategic Approach, Irwin INC, USA. New York.

[46]. Ohno, T. (2002).Toyota Production System. Productivity Press, New York.

[47]. Okumu,F. (2003): A framework to implement strategies in organizations, Management Decision,Vol 41,9,MCB University Press.

[48]. Olson, E.M., Slater, S.F., and Hult, G.T. (2005). The importance of structure and process to strategy implementation ${ }^{\text {ee }}$. Business Horizons, 48, 47-54.

[49]. Orodho, A.J. and Kombo, D.K (2002).Research Methods. Nairobi; Kenyatta University. Institute of Open Learning.

[50]. Patton, M. Q. (1997). Utilization-focused evaluation: The new century text. Thousand Oaks: Sage.

[51]. Peng, W., and Litteljohn, D. (2001). „Organizational Communication and Strategy Implementation-A Primary Inquirye. International Journal of Contemporary SHospitality, 13, 360-363.

[52]. Pitts, R.A.and Lei, D.(1995), Strategic Management Building and Sustaining CompetitivePlanning Education and Research. 14:173178.Research. 14:163-166.

[53]. Prahalad, C.K. and Hamel, G. (1990). "The core competence of the corporation”. Harvard Business Review, Vol. 68, Spring, pp. 79-91. 